\title{
A propósito de imigração e urbanização: correntes imigratórias da Itália meridional às "outras Américas"1
}

\author{
VITTORIO CAPPELLI*
}

Resumo: O presente ensaio tem como tema a imigração italiana na América Latina, a partir da análise de pequenos fluxos espontâneos direcionados para regiões ou para países marginais àqueles privilegiados pela imigração de massa. Tais fluxos são, em grande parte, constituídos por correntes imigratórias oriundas de pequena área na Itália meridional, que estimulam uma experiência de mobilidade, relacionada principalmente à atividade dos pequenos comerciantes e dos artesãos, alcançando significativa contribuição para a construção das modernas redes urbanas.

\begin{abstract}
The following essay has the Italian immigration in Latin America as its topic, analyzing small, spontaneous flows of immigrations which were directed into regions or marginal countries, privileged by the mass. Those flows are in its vast majority formed by immigration movements, originated from a small meridian area in Italy, which stimulates a mobility experience related mainly to activities of small merchants or to artisans, having a significant contribution to the construction of urban networks.
\end{abstract}

Palavras-chave: Imigração italiana. Regiões periféricas latino-americanas. Urbanização.

Key words: Italian immigration. Peripherical Latin-American regions. Urbanization.

1 O texto reproduz, sem modificações substanciais, mas com algumas adaptações e inserções, a palestra de abertura apresentada no VI Congresso Internacional de Estudos Ibero-Americanos, promovido pelo Programa de Pós-Graduação em História da Pontifícia Universidade Católica do Rio Grande do Sul, Porto Alegre, de 16 a 18 de outubro de 2006.

A tradução é de responsabilidade da Profa. Dra. Núncia Santoro de Constantino, docente do Programa de Pós-Graduação em História da PUCRS.

* Professor-associado de História Contemporânea na Universidade da Calábria Itália; dirige a revista de História e Ciências Sociais Daedalus.

Estudos Ibero-Americanos. PUCRS, v. XXXIII, n. 1, p. 7-37, junho 2007 
Tú venías, y el mundo estaba debajo de tus pasos, $y$ debajo de tus noches, $y$ debajo de tus soledades. (...).

Tú, el viajero, el insomne, el descontento, el que levantaba las manos hacia los relámpagos, el que veía pasar las bahías como la orilla serena y brumosa de la tristeza. Sabias soportar las lejanías, siempre tan del corazón.

Sabías llegar.

Y eras ahí el anónimo, el oscuro, el devorado, tendido en las noches calientes, como los sacos, como los barriles, a la orilla de los grandes navios. (...). Tú estabas dormido bajo las estrellas de otro mundo. Padre mio, padre de mi universal angustia. $Y$ de mi poesia.

Vicente Gerbasi Mi padre, el inmigrante

(Caracas, 1945)

\section{As cartas na mesa}

A relação entre imigração e urbanização é o assunto central destas páginas. De início esclareço que vou analisá-lo de modo empírico, sem a intenção de traçar modelos ou de construir sínteses teóricas. Assim, pretendo formular alguma hipótese interpretativa no âmbito da emigração italiana relacionada à história latino-americana, diga-se de passagem, terreno pouco freqüentado na historiografia.

Tratarei da imigração italiana na América Latina, sem determe nos lugares privilegiados pela imigração de massa, que coincidem com as grandes capitais, as modernas megalópoles; deixarei também de lado as principais áreas de colonização agrícola. Portanto, não falarei de Buenos Aires nem de São Paulo, dando preferência aos traços dos pequenos fluxos imigratórios espontâneos, até hoje descurados ou mesmo ignorados pela historiografia. Estes traços conduzem a áreas periféricas do continente latinoamericano; na verdade conduzem às regiões ou aos países marginais aos grandes fluxos imigratórios europeus.

É este o caso das maiores ilhas do Caribe, Cuba e República Dominicana, da Guatemala, Costa Rica, Colômbia, Equador. É também o caso das regiões periféricas de grandes estados no norte e no nordeste do Brasil. 
Descobriremos que essa emigração espontânea é constituída freqüentemente por correntes migratórias que partem de uma pequena área na Itália meridional, no limite entre as províncias de Cosenza, Potenza e Salerno, portanto entre três regiões italianas: Calábria, Basilicata e Campânia. Trata-se de uma parte do Apenino meridional, onde o fenômeno da emigração para as Américas manifesta-se de forma precoce, já a partir da década de 1860, estimulando uma ativa experiência de mobilidade, relacionada a hábitos dos vendedores ambulantes e, sobretudo, ao articulado mundo dos artesãos: douradores, artífices em estanho e em cobre, cinzeladores, prateiros, ourives, caldeireiros, fabricantes de instrumentos de corda, tintureiros, alfaiates, sapateiros. ${ }^{2}$

O espírito de iniciativa e o uso de estratégias familiares de mobilidade geográfica e social fizeram com que esta emigração representasse um momento inicial de estímulo à grande emigração de massa, delineando acontecimentos imigratórios que desmentem de maneira sonora persistentes estereótipos sobre uma emigração que seria mais grosseira e inculta do que outras, desqualificada profissional e socialmente.

A subjetividade que impulsiona esta experiência migratória contradiz e desmente a idéia formulada pelo grande Fernand Braudel, a propósito das montanhas mediterrâneas, que ele entendia como una "fábrica de homens", decorrente da presumida imobilidade social e cultural dos lugares de partida, que teriam expulso do seu seio os indivíduos, segundo a lógica elementar e brutal da necessidade. ${ }^{3}$ As experiências migratórias concretas a que nos

2 Cf. Cappelli, Vittorio. Entre inmigrantes, socialistas y masones. La emigración italiana en Colombia y en Centroamérica y un fantasmal atentado a Mussolini. Estudios Migratorios Latinoamericanos, ano 19, n. 57, agosto 2005, p. 335-365; Cappelli, Vittorio. Regioni migratorie e regioni politico-amministrative. L'emigrazione verso le "altre Americhe" da un territorio di frontiera calabro-lucano-campano. Archivio Storico dell 'Emigrazione Italiana, ano 3, n. 1, 2007, p. 55-66; Cappelli, Vittorio. Verso le Americhe. Alle origini dell'emigrazione transoceanica in Calabria e in Lucania. Apollinea, ano 9, n. 6, novembre-dicembre 2005, p. 32-37; depois em Il Folklore d'Italia, n. 1, 2006, p. 51-56 (www.sissco.it/saggi/pdf/cappelli_americhe.pdf). Para a análise de um caso análogo nos Apeninos centro-meridionais, leia-se a estimulante contribuição de Massullo. G. Molise: grande emigrazione e mobilità territoriale. Trimestre, XXXVII/3-4, 1994, p. 497-521; Massullo, G. Mobilità territoriale e quadri ambientali in Molise tra Otto e Novecento. In: Albera, D.; e Corti, P. (orgs.). La montagna mediterranea: una fabbrica d'uomini? Mobilità e migrazioni in una prospettiva comparata (secoli $X V-X X)$. Cavallermaggiore: Gribaudo, 2000, p. 141-152.

3 Este assunto é desenvolvido no citado volume sobre A montanha mediterrânea, no qual leia-se particularmente o ensaio introdutivo de D. Albera e P. Corti, Movimenti migratori nell'arco alpino e nella montagna mediterranea: questioni e prospettive per un'analisi comparata (p. 7-27). 
referimos parecem, ao invés, dizer outra coisa. Além do mais, remetem ao extraordinário e paralelo dinamismo migratório síriolibanês - para ficar no mundo mediterrâneo, na vertente árabe do meio-oriente -, que também apresenta esses notáveis elementos de ousadia e de subjetividade. ${ }^{4}$

Mas prometi não dissertar sobre paradigmas, modelos e teorias. Então limitamo-nos a observar apenas que esses emigrantes na maior parte das vezes artesãos e camponeses pequenosproprietários - excluem do seu horizonte a perspectiva de trabalho agrícola, assim como o isolamento em ambientes rurais; todavia também evitam, se possível, as grandes capitais. Preferem os pequenos centros urbanos, como acontece, por exemplo, na América Central e no norte do Brasil. Não é raro escolherem cidades portuárias em desenvolvimento na virada para o século XX, como Barranquilla, na Colômbia, ${ }^{5}$ ou Guayaquil, no Equador. ${ }^{6}$

4 É de grande interesse a emigração espontânea do Líbano, da Síria e, em qualquer medida, da Palestina, dirigida para o Brasil e para a Argentina, mas também para numerosos países sul-americanos, do Chile à Colômbia, assim como à América Central e ao Caribe. A diversidade de destinos esboça grande número de diferenciadas situações que, entretanto, sempre apresentam características comuns, como uma acelerada atividade econômica e social das correntes migratórias; também é comum a questão cultural do preconceito com relação a estes imigrantes, definidos todos indistintamente como "turcos", porque possuíam o passaporte do Império Otomano que, como se sabe, estendia os seus domínios até o Oriente Próximo antes da Primeira Guerra Mundial. Para o Brasil cf. Truzzi, O. Libanais et Syriens au Brésil (1880-1950). REMI. Revue Européenne des Migrations Internationales, vol. 18, n. 1, 2002, (http://remi.revues.org/document1694.html); para a Colombia cf. Fawcett, L.; Posada Carbó, E. Árabes y Judíos en el desarrollo del Caribe colombiano, 1850-1950. Boletín Cultural y Bibliográfico, vol. 35, n. 49, 1998

(www.lablaa.org/blaavirtual/publicacionesbanrep/boletin/boleti1/bol49/491.pdf); Hoz, J. Viloria de la. Lorica, una colonia árabe a orillas del río Sinú. Cuadernos de Historia Económica y Empresarial, n. 10, luglio 2003

(www.banrep.gov.co/docum/Pdf-econom-region/Cuadernos/CHEE10-Lorica.pdf). Não é raro, por outro lado, encontrar acontecimentos da imigração sírio-libanesa na literatura latino-americana; um interessante caso de observação "do interior" é um romance do escritor brasileiro de origem libanesa, ambientado em Manaus, cuja leitura é útil também para uma adequada percepção da relação centro-periferia no Brasil: Due Fratelli, Milano: Marco Tropea Editore, 2005. [Publicado no Brasil: Dois Irmãos. São Paulo: Companhia das Letras, 2003 - N. T.].

Com relação aos palestinos, cf. Jardim, D. Fagundes. Os imigrantes palestinos na América Latina. Estudos Avançados, Universidade de São Paulo, vol. 20, n. 57, 2006, p. 171-181. Útil síntese da completa experiência imigratória está em Spagnesi, G.. Le élite arabe in America Latina. Equilibri, Dossier, n. 9, 2005

(www.equilibri.net/search.php?q=elite+arabe).

5 Cf. Cappelli, V.. Tra "Macondo" e Barranquilla. Gli italiani nella Colombia caraibica dal tardo Ottocento alla Seconda guerra mondiale. Altreitalie, n. 27, luglio-dicembre 2003, p. 18-52 (www.altreitalie.it).

6 Cf. Carducci, L. Guarnieri Calò. Dizionario storico-biografico degli italiani in Ecuador e in Bolivia. Bologna: Il Mulino, 2001. 
É importante salientar que isto ocorre no mesmo período em que a história urbana da América do Sul supera a fase da cidadecapital, entrando naquela fase mais articulada da rede urbana, composta de numerosas cidades, pequenas e médias, assim como de novos municípios. Em 1870, as cidades com mais de 100.000 habitantes eram somente seis em toda a América do Sul; em 1900 tornam-se 13, e em 1930 são 35. No Brasil, no início do século XX, $10 \%$ da população vivia em cidades com mais de 10.000 habitantes. Os municípios, que eram 618 em 1871, tornam-se 1.168 em 1910; entre 1871 e 1920, aqueles que tinham como sede uma cidade com 5.000 habitantes, no mínimo, se quadruplicaram entre 1871 e 1920, passando de 200 a 800 municípios. ${ }^{7}$

São eloqüentes os dados quantitativos, mas procurarei não aborrecer com números. Por isso, seguiremos vestígios desses migrantes italianos, cuja intuição conduzirá por vezes a lugares distantes e escondidos, como a pequena cidade de Quetzaltenango, em plena atividade no alvorecer do século XX, depois de um terremoto nos Altos del Guatemala, onde a cidadezinha é capital; ou a colombiana Ciénaga, à época da "bonança bananeira", tornada célebre na mítica "Macondo" de Gabriel García Márquez; ou ainda as cidades de Santarém e Óbidos, na Amazônia, florescentes durante o boom da borracha e do seu comércio internacional.

$\mathrm{Na}$ maior parte das vezes, entretanto, encontraremos esses migrantes, que partiram de lugares quase inacessíveis do Apenino Meridional, em pequenas cidades portuárias: Colón, Panamá, Barranquilla, Santa Marta, Belém e portos fluviais da Amazônia, Recife, Aracaju, Salvador e, enfim, Porto Alegre - envolvidos no comércio, no artesanato e por vezes na pequena indústria, evitando as complicações e a particular dureza da seleção social própria das grandes capitais, como Buenos Aires e São Paulo, repletas de migrantes italianos e europeus.

Imagino que seguir essa experiência permitirá situar o caso dos "moraneses", ou seja, dos calabreses de Porto Alegre - estudados admiravelmente por Núncia Santoro de Constantino, ${ }^{8}$ - inse-

7 Cf. Carmagnani, M.. L'altro Occidente. L'America Latina dall 'invasione europea al nuovo millennio. Torino: Einaudi, 2003, p. 270-273.

8 Constantino, desde o final da década de 1980, chama a atenção sobre os calabreses de Porto Alegre, documentando amplamente o caráter urbano desta imigração, a sua origem em Morano Calabro, assim como os processos de integração e os êxitos sociais na capital do Rio Grande do Sul. Resulta a descrição de um caso radicalmente diferente daquele da imigração em caráter rural dos colonos vênetos, assentados no território agrícola de Caxias do Sul, nos moldes da precedente imigração alemã. Cf. Constantino, N. Santoro de. Immigranti calabresi a Porto Alegre (Rio Grande do Sul, Brasile). Daedalus, n. 1, 1988, p. 165-183; Constantino, Nuncia Santoro de. O Italiano 
rindo-os em ampla e articulada experiência que confirma e destaca algumas características da comunidade calabresa desta cidade e ajuda também a compreender as origens, a lógica e êxitos desta tipologia migratória. Como se sabe, tal experiência, estruturandose espontaneamente sobre ligações familiares e parentais, valendose da proteção de redes de amizade e de vizinhança, evocando a identidade de sua aldeia, tende a concentrar os fluxos migratórios de cada um dos seus paesi de origem sobre uma ou poucas destinações, onde fosse possível, de alguma forma, reproduzir os laços de solidariedade que oportunizaram o projeto migratório, para proteger e tornar produtivo o investimento inicial.

Assim, os moraneses ficam em Porto Alegre, ainda que também formem comunidades em Barranquilla, San José di Costa Rica e na guatemalteca Quetzaltenango. ${ }^{9}$ Por outro lado, os emigrantes lucanos de Trecchina formam comunidades grandes em Jequié, no estado brasileiro da Bahia, ${ }^{10}$ os calabreses de Tortora formam grupo em Fortaleza ${ }^{11}$ e aqueles de Laino Borgo são encontrados em Salvador. ${ }^{12}$ Em Santarém e Óbidos, na margem do rio Amazonas, todos os italianos chegam de San Costantino di Rivello, um pequeno paese da Basilicata, ${ }^{13}$ e à capital amazonense, Manaus, muitos vêm de Castelluccio Inferiore, outro paesino lucano na fronteira

da esquina. Porto Alegre: EST, 1991. Para uma recente visão de conjunto cf. Constantino, N. Santoro de; Ribeiro, C. Piazza Julio (orgs.). De pioneiros a cidadãos. Imagens da Imigração Italiana no Rio Grande do Sul (1875-1960). Porto Alegre: Consulado Geral da Italia, 2005. É preciso registrar, todavia, que os estudos bem mais numerosos dizem respeito à colonização vêneta e se concentram últimamente sobre aspectos culturais, antropológicos e religiosos, com análises cada vez mais sofisticadas. Cf. Ribeiro, C. Piazza Julio; Pozenato, J. Clemente (orgs.). Cultura, Imigração e Memória. Percursos $\mathcal{E}$ Horizontes. Caxias do Sul: EDUCS, 2004; Vannini, I. A. O sexo, o vinho e o diabo. Demografia e sexualidade na colonização italiana no Rio Grande do Sul (1906-1970). Passo Fundo/Porto Alegre: UPF/EST, 2004; Possamai, P. "Dall 'Italia siamo partiti”. A questão da identidade entre os imigrantes italianos e seus descendentes no Rio Grande do Sul (18751945). Passo Fundo: UPF, 2005.

9 Cf. Cappelli, V. Nelle altre Americhe. Calabresi in Colombia, Panamá, Costa Rica e Guatemala. Doria di Cassano Jonio: La Mongolfiera, 2004.

10 Araújo. E. Pinto de História de Jequié. Salvador: Imprensa oficial da Bahia 1971 (nova edição: 2006); Marotta, C. e C. Casa Confiança. Carmignano: Attucci Editrice, 2004.

11 Aliprandi, E.; Martini, V. (orgs.). Gli italiani nel nord del Brasile. Rassegna delle vite e delle opere della stirpe italica negli stati del nord brasiliano. Belém: Tip. da Livraria Gilet, 1932.

12 Rosa, L. De. Emigranti, capitali e banche (1896-1906). Edizione del Banco di Napoli, ivi, 1980, p. 48.

13 Ronca, G. Dalle Antille alle Guyane e all'Amazzonia. Annali della Società Geografica, 1908 (www.solofrastorica.it/amazzoniaviaggio.htm) (o autor está equivocado, pois, na verdade, fala de San Costantino Albanese); Pinto, W. No rastro da imigração italiana, 2006 (www.ufpa.br/beiradorio/arquivo/beira29/noticias/noticia3.htm). 
com a Calábria. ${ }^{14}$ A colônia italiana de Santo Domingo chega da calabresa Santa Domenica Talão, ${ }^{15}$ aqueles do Panamá e de Havana chegam em grande parte de Castrovillari, ${ }^{16}$ imigrantes no Caribe colombiano vêm de Morano, Scalea, Padula e Castelnuovo di Conza. ${ }^{17}$ Trata-se sempre de paesi compreendidos no território que havíamos assinalado.

Os persistentes laços comunitários, todavia, não criaram obstáculos aos processos de integração que, ao contrário, serão com freqüência rápidos, também graças às limitadas dimensões quantitativas das comunidades dos migrantes, cujo peso específico tem alguma significação em pequenas cidades. As atividades comerciais e artesanais, entretanto, não seriam "auto-alimentadas" pela crescente clientela de conterrâneos migrantes, como aconteceu, por exemplo, no mundo urbano paulista ${ }^{18}$ ou em Buenos Aires. Ao contrário, devem ser consideradas, desde o início, em relação ao mercado global das cidades e das regiões de acolhimento. Assim, os nossos migrantes acabaram por dar uma contribuição elevada ao desenvolvimento geral dos mercados e, às vezes, a todo o sistema produtivo das cidades e das regiões de destino.

Não é de pouca importância que isso ocorra na fase histórica em que as cidades do subcontinente sofrem um vistoso processo de transformação urbanística, "visível na ruptura da planta ibérica, ou seja, da 'quadrícola' derivada do 'castrum' romano, com a construção de avenidas, parques, praças e monumentos dedicados a heróis nacionais". ${ }^{19}$ Esse processo vem acompanhado também pela diferenciação laica das funções e dos espaços civis e religiosos, antes confundidos e entrelaçados, além de comportar a modernização que exige competência profissional, técnica e artística, indisponível na sociedade local.

Portanto, outros italianos alcançam as pequenas cidades mencionadas, atraídos pela expansão urbana e pela oportunidade de construir edifícios públicos e privados, de reorganizar praças e espaços públicos, colocando monumentos e outros elementos decorativos. Arquitetos, mestres-de-obras e artistas italianos provi-

\footnotetext{
Aliprandi; Martini (orgs.), Gli italiani nel nord del Brasile, cit.

Azcárate, G. Los italianos en America. Historia de familia, 2002

(www.rootsweb.com/ domwgw/italianosamerica.htm).

16 Cappelli, Verso le Americhe, cit.

17 Cappelli, Tra “Macondo” e Barranquilla, cit.

18 Cf. Trento, A.. Gli italiani nel mondo urbano paulista (1880-1920). In: Trentamila 'tirolesi' in Brasile. Storia, Cultura, Cooperazione allo sviluppo, Atti del Convegno tenutosi a Trento il 2 e il 3 febbraio 2001

(www.regione.taa.it/GIUNTA/conv/brasile/programma.htm).

19 Carmagnani, L'altro Occidente, cit., p. 269.
} 
denciam os projetos, a execução e a decoração de igrejas e teatros. A igreja, como insubstituível ponto de referência para a população e lugar da tradicional sacralização do poder pela oligarquia local; os teatros, como lugares de reconhecimento, auto-representação e auto-celebração da renovada e "moderna" elite urbana na virada para o século XX.20

Tudo isto é promovido pelas elites econômicas e políticas latino-americanas, com os olhos voltados à Europa e preferindo a França como modelo cultural, país inspirador dos sinais estéticos da expansão urbana. Mas é curioso observar que o veículo real do "francesismo" e do mito de Paris - triunfante e presente por todos os lugares - seja na realidade quase sempre realizado por profissionais e artistas italianos. Com freqüência são eles a introduzir concretamente o modernismo e o ecletismo europeu na arquitetura, na decoração e na pintura.

Seja como for, permanece o fato de que essa migração intelectual e artística, somada àquela camponesa e artesã, com a qual algumas vezes se confunde, termina por enriquecer o cenário da presença italiana no pequeno mundo urbano desta América "menor", periférica, mas nunca imóvel.

\section{No Brasil: Bahia, Sergipe, Pernambuco, Paraíba...}

Neste ponto, continuamos com a observação empírica, partindo do nordeste brasileiro, mais exatamente de Salvador e do estado da Bahia.

Poderá surpreender que se fale de imigração italiana na cidade mais africana do Brasil, habitada por larga maioria de negros e mulatos, uma ex-capital em declínio nos anos sessenta do século XIX. ${ }^{21}$ Contudo, Thales de Azevedo, há muito tempo já assinalava

20 Este é um tema que mereceria uma investigação sistemática, a exemplo dos estudos de Regina Soria para os Estados Unidos. Cf. Soria, R. Fratelli lontani. Il contributo degli artisti italiani all'identità degli Stati Uniti (1776-1945). Napoli: Liguori, 1997; Soria, R. American Artists of Italian Heritage, 1776-1945. A Biographical Dictionary. London and Toronto: Associated University Presses, 1993.

21 Essa idéia é predominante entre os estudiosos brasileiros, os quais afirmam que a Bahia viveu um "longo século XIX", por causa do seu declínio econômico e da persistência de uma mentalidade ancorada nas glórias e mitos da grandeza de um passado. Mas é também verdade que, apesar do seu relativo "ilhamento", a Bahia continuava a ser uma "praça" muito interessante para comerciantes, em boa parte estrangeiros, que exportavam açúcar, algodão, tabaco e cacau, conferindo à cidade de Salvador, no século XIX, um certo ar cosmopolita. Não faltam, de outra parte, os estudiosos que contestam integralmente a idéia da decadência de Salvador e do estado da Bahia no mesmo período. A totalidade da questão é retomada por Oliveira, P. C. 
uma presença dos italianos bem mais significativa do que se pensa comumente. Ele recorda que, em 1861, existia em Salvador uma "Sociedade Italiana de Recreio e Beneficência".22 E pouquíssimos anos depois, teriam chegado de Trecchina, um pequeno paese da Basilicata no limite com a Calábria, os primeiros imigrantes espontâneos que deram vida, a partir de 1878, à uma ativa e interessante colônia italiana em Jequié, promovendo com originalidade o comércio e a agricultura. ${ }^{23}$ Tanto que, dos 200.000 habitantes atuais de Jequié, pelo menos 2.000 são de origem italiana.

Essa corrente migratória de Trecchina encontra ampla repercussão no vizinho município calabrês de Laino Borgo, a julgar pela informação do cônsul italiano L. S. Rocca. Segundo ele, deste pequeno paese provêm quase todos os 500 italianos presentes na Bahia no início do século XX século. ${ }^{24}$ Muitos eram sapateiros e concentraram-se, na virada para o século XX, na Baixa dos Sapateiros, no Maciel e nas ruas vizinhas de Salvador, onde são numerosas as lojas de calçados e de tecidos, os empórios e as oficinas mecânicas dirigidas por italianos, que têm todos a mesma proveniência geográfica e que trabalham há muito tempo ao lado de comerciantes árabes e judeus. ${ }^{25}$

Por certo, a essa corrente imigratória pertence também o proprietário do "Café Catapano", onde se reuniam, entre 1901 e 1911, os artistas e literatos da revista simbolista Nova Cruzada, dirigida por Carlos Chiacchio, de evidente origem italiana, que por muitos anos seria o principal e incansável intelectual modernista da cidade, abrindo uma brecha na cultura obstinadamente tradicional da oligarquia branca de Salvador. ${ }^{26}$ Simultaneamente, a presença italiana torna-se inconfundível em algumas áreas centrais da cidade: fala-se só italiano na "Pastelaria Triunfo", na esquina entre a Baixa dos Sapateiros e a Ladeira da Saúde, ponto de encontro dos italianos. ${ }^{27}$

Miguez de. Dois séculos e duas medidas. In: A organização da cultura na "cidade da Bahia”. Salvador: Universidade Federal da Bahia, Faculdade de Comunicação 2002 (tese de doutorado), p. 109-157.

22 Azevedo, T. de. Italianos na Bahia e outros temas. Salvador: Empresa Gráfica da Bahia, 1989.

23 Araújo, História de Jequié, cit.; Marotta, Casa Confiança, cit.

24 Cf. Rosa, Emigranti, capitali e banche, cit., p. 48.

25 Azevedo, Italianos na Bahia, cit., p. 34.

26 Cf. Oliveira, A organização da cultura na "cidade da Bahia”, cit.; Soares, A. Barroso Costa. Academia dos rebeldes: modernismo à moda baiana. Feira de Santana: Universidade Estadual de Feira de Santana, 2005 (dissertação de mestrado).

27 Passarela do álcool. Catalano foi um dos primeiros bares da Bahia na primeira metade do século XX. Correio da Bahia, 7 de julho de 2001. 
A esta altura, verificava-se na Bahia uma fase de retomada do desenvolvimento econômico, graças, sobretudo, ao cacau. Diante da rápida modernização de Salvador, em processo particularmente acentuado durante o governo di Seabra (1912-16), ${ }^{28}$ verificam-se transformações que, inovando, produzem também efeitos destrutivos sobre o patrimônio histórico da cidade, sem alcançar, todavia, alterações na ordem social tradicional e pré-moderna. Seja como for, alguns arquitetos italianos tomam parte na reforma urbanística da cidade, acrescentando um outro cunho à composição da pequena colônia italiana, proveniente do Apenino calabrolucano. Alguns expoentes desta colônia, nas décadas de 1920 e 1930, além de ingressarem naqueles nichos já ocupados por conterrâneos no comércio e no artesanato, encontram espaço na pequena indústria. No início dos anos 1930, encontram-se ativas uma fábrica de bebidas, uma fábrica de sapatos, outras duas de massas alimentícias e de laticínios. ${ }^{29}$

Por fim, verifica-se que essa experiência migratória tem também sedimentação cultural e artística. Se, nos anos 1930 se registra uma curiosa "Barbearia Futurista", homenageando o movimento de vanguarda fundado por Marinetti, mais importante é registrar que, entre os artistas baianos do século XX e de notoriedade nacional, encontramos o pintor Sante Scaldaferri, nascido em 1928, e a designer Lidia Bloisi, nascida em 1943, cujos sobrenomes remetem àquele território montanhoso que está entre a Calábria e a Basilicata, do qual partiram os primeiros imigrantes. Mas não se trata somente de êxitos culturais e elitistas, pois Thales de Azevedo identificou 250 sobrenomes italianos na Bahia. Examinando-se uma amostra atual, constituída por 146 famílias baianas de origem italiana, concluímos que mais de $30 \%$ dos sobrenomes remete aos mesmos lugares calabro-lucanos, confirmando a estabilidade desta experiência imigratória. Assim, a aventura de alguns milhares de italianos é enfim integrada nas poderosas mudanças ocorridas em Salvador nos últimos decênios, às quais os peninsulares deram sua

28 José Joaquim Seabra (Salvador, 1855 - Rio de Janeiro, 1942), que foi parlamentar e ministro, é talvez o mais notável governador da Bahia no século XX, conhecido pela radical modernização urbanística de Salvador, por ele imaginada pensando no "saneamento" urbano, anteriormente realizado no Rio e, antes de tudo, na Paris de Haussmann e nos seus boulevards. Desta forma, em Salvador, igrejas e edifícios coloniais deram lugar a novas artérias e iniciou-se a falar numa "Renascença Bahiana". Cf. José Joaquim Seabra, o arquiteto da modernidade. Revista Bahia invest (www.seplan.ba.gov.br/bahiainvest/port/perfil.php?find=versao006).

29 Cf. Andrade, M. Correia de. A Itália no Nordeste. Recife: Fundação Joaquim Nabuco, Editora Massangana, 1992, onde se utiliza principalmente como fonte: Aliprandi e Martini, Gli italiani nel nord del Brasile, cit. 
contribuição, mesmo nos distantes tempos de declínio e estagnação na região de acolhimento.

Transferimo-nos agora da Bahia para o vizinho estado de Sergipe, na pequena Aracaju, onde o número de italianos é muito menor. Entretanto, nesta modesta presença, encontram-se múltiplos e justificados motivos de interesse. A proveniência geográfica é sempre a mesma: o território compreendido entre as províncias de Salerno e de Cosenza. A tipologia migratória é a mesmíssima, mas com traços sociais mais elevados: os italianos de Aracaju são comerciantes, empreendedores e artistas, que deram uma contribuição decisiva à renovação urbana da pequena capital de Sergipe na primeira metade do século XIX. ${ }^{30}$

$\mathrm{O}$ mais conhecido pioneiro da pequena colônia italiana é o comerciante Nicolau Pungitori (1845-1909), 31 que construiu o teatro "Carlos Gomes", em 1903. Os expoentes mais lembrados da geração sucessiva italiana são Nicola Mandarino (1883), de Vibonati-Campania, e Federico Gentile (1888-1970), calabrês de Paola: o primeiro, proprietário de uma grande marcenaria, em Aracaju, de uma fábrica de sabão e de um depósito de tecidos; o segundo, ativo construtor civil, junto com o irmão Attilio.

Mandarino conquista um posto de primeiro plano na elite sergipana e, por isso, será alvo fácil das manifestações antiitalianas no verão de 1942, depois do afundamento de um navio mercantil brasileiro por submarino alemão, no largo de Aracaju, provocando mais de duzentas mortes. Gentile faz parte da dita "Missão artística italiana" que, a partir de 1918, renova visivelmente o equipamento urbano da cidade. Trabalham Bellando Bellandi (arquiteto), Oreste Gatti (pintor), Bruno Cercelli (escultor e decorador), Raffaele Alfano (cinzelador), Hugo Bozzi (construtor). Em particular, destaca-se o arquiteto Bellandi, restaurador da fachada do palácio do governo em estilo eclético, que se torna modelo imprescindível para as residências dos ricos de Aracaju; Gentile, que é o construtor mais importante da cidade, constrói muitas vilas para a oligarquia local e para os italianos enriquecidos, prédios em que insere elementos modernos, ecléticos e art nouveau, transformando a arquitetura local, segundo a moda européia.

Pertencer à maçonaria torna-se comum e caracteriza a pequena comunidade italiana de Aracaju. Em 1872 é fundada na cidade

30 Cf. Barreto, L. A.. Estrangeiros em Aracaju, 29 de abril; 3,7,9 e 12 de maio de 2005 (www.infonet.com.br/luisantoniobarreto).

31 O sobrenome Pungitori é presumivelmente derivado de uma corruptela de Pungitore ou Pingitore, que são ambos sobrenomes calabreses. 
a Loja Maçônica Cotinguiba, que se destaca pelo grande espaço oferecido aos estrangeiros: alemães, dinamarqueses, holandeses, russos, sírios e italianos em bom número. Dela fazem parte os Pungitori, os Mandarino, os Gentile e outros, contribuindo significativamente para o caráter cosmopolita da Loja, cuja origem está relacionada ao desenvolvimento do tráfico portuário, assim como aos estrangeiros que operam na cidade. No final do século, a loja maçônica transforma-se em ponto de encontro e, pertencer ao seu quadro significa reconhecer a integração de comerciantes estrangeiros na dinâmica urbana. Se Loja Cotinguiba, nos primeiros anos de sua existência, participa da campanha abolicionista e da propaganda republicana, na virada para o século $X X$, graças à participação italiana, européia em geral e árabe, apresenta-se como o mais moderno e eclético instrumento de representação social, desempenhando um papel aglutinados na jovem elite. ${ }^{32}$

Sabemos, todavia, que a adesão à maçonaria era motivo para problemas no Brasil do final do século XIX, apesar de que os maçons estivessem presentes nos altos cargos de Estado. Tanto é que, em 1872 - o mesmo ano da fundação da Loja de Aracaju -, um pouco mais ao norte de Sergipe, o bispo de Olinda-Recife, Dom Vital (1844-1878), entrava em violento atrito com a maçonaria, dando origem à conhecida Questão Religiosa, resolvida provisoriamente com a prisão do Bispo. ${ }^{33}$

Para as finalidades de nossa palestra, entretanto, o aspecto mais interessante é que a atividade maçônica dos imigrantes italianos de Aracaju não é, de nenhum modo, uma experiência isolada. Ao contrário e como veremos, será reencontrada também na Colômbia e na América Central, por iniciativa de imigrantes que têm a mesma proveniência geográfica dos ítalo-brasileiros de Sergipe. E este é um dos temas que ainda esperam por uma reflexão.

Mas prosseguimos com a nossa resenha.

Os imigrantes de Recife têm a mesma origem geográfica dos italianos de Salvador e de Aracaju. Muitos desses imigrantes chegam da pequena Trecchina e de outros paesi da Basilicata. Também a composição social e os percursos de integração são semelhantes:

Cf. Barreto, Estrangeiros em Aracaju, cit.

33 O acontecimento evidencia a ignorância de uma parte da Igreja; a violenta campanha contra a maçonaria promovida por Dom Vital foi atenuada pelo Cardeal Antonelli e mesmo pelo Pontíficie Pio IX. Cf. Pereira, N. Dom Vital e a Questão Religiosa no Brasil. Recife: Imprensa Universitária, 1966; Pereira, N. Conflitos entre a Igreja e o Estado no Brasil. Hispanic American Historical Review, vol. 52, n. 1, fevereiro de 1972; Fleichman, Julio. Dom Vital e a Maçonaria. Permanência, novembro-dezembro 1981 (www.permanencia.org.br/revista/historia/vital.htm). 
trata-se de artesãos e de pequenos comerciantes que, com freqüência, começaram como empregados em oficinas e pequenas lojas, ou como mascates na zona rural. Foram inicialmente financiados pelos conterrâneos que lhes precederam e que os convidaram a emigrar. Numerosos eram os artesãos especializados no trabalho com metais, como caldeireiros, funileiros, fundidores, chamados a partir da multiplicação das usinas de açúcar; muitos também eram alfaiates e sapateiros; e não poucos foram aqueles que se tornaram industriais: no início da década de 1930 encontra-se uma fábrica di licores e de gasosas, uma indústria de tecidos, a fundição "Vesúvio", outras indústrias metalúrgicas e de calçados. ${ }^{34}$

Mais do que em outras cidades, parece que no Recife houve uma relação estreita entre ofícios artesanais e atividades industriais, sendo freqüente a passagem de uns às outras. Em suma, a capital pernambucana confirma as características fundamentais da presença italiana em todo o nordeste. Entretanto, talvez fosse mais acentuada a presença em indústrias e menor a participação na expansão e nas reformas urbanas, a exemplo de Aracaju; exceções foram o mausoléu a Joaquim Nabuco, ${ }^{35}$ executado por Giovanni Nicolini (1910), e o Palácio de Justiça, em estilo renascentista, de Giacomo Palumbo (1930). 36

No plano artístico, também é preciso destacar a presença do pintor Murillo La Greca, nascido em 1899, caçula dos doze filhos do casal de imigrantes Vincenzo La Greca e Teresa Carlomagno, provenientes de diferentes lugares dos confins calabro-lucanos. Tendo herdado juntamente com os irmãos a usina açucareira de Palmares, perto de Recife, o jovem La Greca realizará sua formação artística baseada nos indiscutíveis cânones clássicos, inicialmente no Rio de Janeiro e depois em Roma, onde aprendeu a técnica do afresco. Retornando para sempre ao Brasil às vésperas da Segunda Guerra Mundial, é contratado para pintar os afrescos da

34 Aliprandi e Martini, Gli italiani nel nord del Brasile, cit.; Andrade, A Itália no Nordeste, cit.

35. O monumento, realizado em mármore de Carrara e colocado no cemitério de Recife, exalta a contribuição do homem político à abolição da escravatura no Brasil.

36 O arquiteto Giacomo Palumbo, projetista de outras obras públicas no Recife, neste contexto é lembrado, sobretudo, por ter sido o autor do moderno plano de desenvolvimento urbano de Natal, capital do Rio Grande do Norte (1929-30). Cf. Dantas, G. A. Ferreira; Dantas, A. C. de Carvalho Lopes; Ferreira, A. L. A. Ecletismo e Modernidade em Giacomo Palumbo - arquitetura e urbanismo nos anos 1920 e 1930. In: Dantas, G.; Ferreira, A. (orgs.). Surge et Ambula: A construção de uma cidade moderna. Natal, 1890-1940. Natal: EDUFRN, 2006, p. 199-214. 
Basílica de Nossa Senhora da Penha, em Recife, construída em 1870 nos moldes arquitetônicos de Palladio. ${ }^{37}$

Enfim, do ponto de vista quantitativo, a presença italiana em Recife é a mais consistente de todo o nordeste. Tanto é que, ainda hoje, ali residem cerca de dois mil cidadãos italianos, além de dezenas de milhares de descendentes. ${ }^{38}$ Ao contrário, no estado limítrofe da Paraíba, encontram-se arquitetos e construtores italianos que permitem imaginar uma situação semelhante àquela encontrada em Aracaju, onde se destaca o aspecto qualitativo. ${ }^{39}$

\section{Ainda no Brasil: Pará e Amazonas}

Posteriores elementos de interesse apresenta a surpreendente imigração italiana nos estados do norte, principalmente em Belém, Santarém e Óbidos, no Pará, e em Manaus, no Amazonas. Também desta vez trata-se de uma imigração proveniente do mesmo território no Apenino meridional, atraída pelo mítico boom da "borracha", cujo ciclo se estendeu entre 1870 e 1920, e no qual esses italianos procuram inserir-se de qualquer maneira. ${ }^{40}$

É conhecido o vibrante desenvolvimento urbano de Belém que, em 1904, tem 125.000 habitantes, o triplo de trinta anos antes, graças ao boom do comércio internacional da borracha. No final do século XIX, na cidade também se iniciava um processo de industrialização, com o surgimento de oficinas mecânicas e pequenas fábricas de sabão, cera, biscoitos, licores, etc.

Seja no comércio citadino, seja na pequena indústria, encontramos uma centena de italianos também em Belém. Muitos são

37 Na capital pernambucana foi inaugurado em 1985 o "Museu Murillo La Greca" e, por ocasião do centenário de nascimento do artista foi publicada a monografia: Melo, C. A. Barreto Campalo de; Borba, F. de Barros. Murillo La Greca. Sua arte, sua vida. Recife, 1999.

38 Cf. La presenza italiana nella circoscrizione consolare di Recife, 2004

(www.embitalia.org.br/Consolare/Circons_Recife.htm). Veja-se também: Ambasciata d' Italia, Istituto Italiano di Cultura. Presenza italiana in Brasile. Cenni sulle collettività. San Paolo, s. d. (ma 1999).

39 Em João Pessoa, a pequena capital da Paraíba, funciona desde 1890 la "Società Italiana di Beneficenza XX Settembre" (denominação laica e maçônica "XX Settembre", mantida ainda em 1932, portanto bem depois da reconciliação entre o Estado e a Igreja decorrente dos Pactos Lateranenses); na década de 1930, aparecem arquitetos e construtores como Ermenegildo Di Lascio e Giovanni Gioia, presidentes, respectivamente, da Società di Beneficenza e del Fascio cittadino, fundado em 1929. Cf. Aliprandi e Martini, Gli italiani nel nord del Brasile, cit.

40 Sobre o ciclo da borracha é recomendável a leitura da monografia de Weinstein, B. A borracha na Amazônia: expansão e decadência, 1850-1920. São Paulo: Hucitec-Edusp, 1993. 
sapateiros, operários, vendedores de fruta. Por iniciativa dos italianos Conte e Libonati, surgem as primeiras fábricas de sapatos. Mais uma vez, esses sobrenomes remetem à mesma zona do Apenino lucano, entre a Calábria e a Campania. No final do século XIX, quando vivem em Belém cerca de quinhentos italianos, é movimentada a linha de navegação Genova-Manaus, empreendimento da Società di Navigazione Ligure-Brasiliana. A colônia cria raízes rapidamente; tanto é que, em 1912, constitui-se uma Associazione Culturale Italo-Brasiliana, contando com algumas centenas de sócios fundadores. ${ }^{41}$ No censo de 1920, registram-se cerca de mil italianos que, nos anos sucessivos, fundam mais duas associações, uma de caráter elitista, outra de caráter mais popular, ambas em permanente competição. Neste momento, quando encerrava o ciclo da borracha, os italianos eram numerosos no comércio de gêneros alimentícios, tecidos, ferragens e no comércio de produtos regionais, mas também desempenhavam atividades bancárias e ocupavam-se de tipografias. ${ }^{42}$

Na virada para o século XIX, sabe-se que o aspecto peculiar de Belém revelara uma apaixonada imitação da cultura européia, sobretudo, da urbanística parisiense e dos códigos estéticos da capital francesa, traduzida em pronunciada urbanização feita de avenidas arborizadas, jardins e praças, assim como de bibliotecas, museus, escolas e estabelecimentos bancários. No centro deste processo, coloca-se emblematicamente o Teatro da Paz (1878) e, mais tarde, numerosos edifícios ecléticos e art nouveau, como os palacetes Pinho, Bologna, Bibi Costa, Facciola, Montenegro, entre outros, além do Mercado de São Brás, da Basílica de Nossa Senhora de Nazaré, etc. Em resumo, um grande número de artefatos que originaram o mito de uma "Paris na América", como proclama o nome de uma grande e suntuosa loja daquele tempo; isso para não mencionar o mais conhecido café de Belém, não por acaso denominado Moulin Rouge. ${ }^{3}$

Em suma, tomava forma uma verdadeira e peculiar embriaguez cultural, produzindo modalidades construtivas inadequadas ao clima, como também modelos de comportamento por vezes grotescos naquela latitude, utilizados pelos novos ricos da borracha;

41 La presenza italiana nella circoscrizione consolare di Recife, cit.

42 Sobre este assunto, Marília Ferreira Emmi desenvolve uma pesquisa junto à Universidade Federal do Pará, em Belém. Cf. Pinto, W. No rastro da imigração italiana, 2006 (www.ufpa.br/beiradorio/arquivo/beira29/noticias/noticia3.htm).

43 Cf. Derenji, J. Arquitetura Nortista. A presença italiana no inicio do século XX. Manaus: SEC, 1998; Lucarelli, F. Scene dall'Amazzonia. Twice told tales. Ruolo e presenza degli italiani (2 vols.). Napoli: Edizioni Scientifiche Italiane, 2005. 
é o caso de vestir camisas engomadas, pretensiosos ternos de lã, ou ainda de submeter-se à tortura do fraque e da cartola em ocasiões festivas, para exibir o status econômico alcançado. ${ }^{44}$

Não sabemos até que ponto e de que maneira os italianos imigrantes participaram deste tipo de delírio cultural. Porém é certo que o "francesismo" reinante em Belém, na maior parte das vezes, não chega da França, mas da Itália. A começar pelo lugarsímbolo da cidade moderna: o Teatro da Paz, cujo modelo arquitetônico neoclássico é na realidade aquele do Teatro La Scala de Milão. A decoração do teatro esteve a cargo dos pintores italianos Domenico De Angelis e Giovanni Capranesi (1887); o mesmo De Angelis foi contratado para pintar também a Catedral de Belém. Mas, sobretudo nos anos sucessivos, a mais interessante arquitetura eclética e art nouveau são obra de italianos: o Palacete Bolonha (1905), o Palacete Bibi Costa (1905) e o "Café do Parque" do engenheiro de origem italiana Francisco Bologna; as múltiplas obras de Filinto Santoro, calabrês de Fuscaldo: o Palacete do governador de Pará, Augusto Montenegro (1904), o Mercado de São Brás (191116), o Colégio Gentil Bittencourt (1895); enfim, a Basílica de Nazaré, projetada por Gino Coppedé, tendo como modelo a Basílica de São Paulo, em Roma. Mas, enquanto o projeto de Coppedé, protagonista de primeira ordem do ecletismo italiano, é uma obra totalmente extrínseca, concebida na Itália e enviada de Gênova em 1909, o arquiteto Filinto Santoro, ao invés, mergulha fundo durante quinze anos no ambiente de Belém e da Amazônia em geral. Todavia, pretende e consegue utilizar materiais, operários, técnicos e artistas italianos na realização dos seus projetos. ${ }^{45}$

Acredito que não seja necessário acrescentar mais nada para ser convincente no que tange à importante participação dos italianos na urbanização de Belém na virada para o século XX. Os traços que deixaram não são somente visíveis na arquitetura e em algumas obras de arte, mas também nos numerosos descendentes que atualmente desempenham atividades no comércio ou profissões liberais.

Entretanto, os italianos não se detiveram em Belém ou mesmo nas bordas da Amazônia. Não foram poucos aqueles que, no

44 Cf. Ronca, Dalle Antille alle Guyane e all'Amazzonia, cit. Uma interessante reflexão sobre a presunção "europeísta" da "civilização da borracha" encontra-se em Mendes, A. Dias. Paris no trópico. Breve roteiro para uma tentativa de identificação da presença do europeísmo, do mimetismo e do saudosismo na cultura da sociedade amazônica "superior". Encontro Regional de Tropicologia, 1, 1984, Caruaru, PE, BR (www.tropicologia.org.br/CONFERENCIA/1984paris_tropico.html). 
final do século XIX, penetraram ao longo dos rios atrás do comércio da borracha e identificam as rotas comerciais. Testemunho desta atividade é Gregorio Ronca, oficial da marinha militar italiana que, em 1905, com um navio oceânico de guerra de 2.200 toneladas, depois de haver percorrido as Antilhas e as Guianas, subiu o rio Amazonas até Iquitos e Santa Fé, no Perú, a 2.285 milhas, ou $4.232 \mathrm{~km}$ do mar, encarregado pelo governo italiano de procurar rotas comerciais e estreitar relações com imigrantes. ${ }^{46}$

O capitão Ronca, no seu longo diário, descreve com pormenores a comunidade italiana encontrada. E, subindo o rio, entre Belém e Manaus, encontra as comunidades mais numerosas e florescentes em Santarém e Óbidos, encruzilhadas comerciais importantes, não só pela borracha, mas também graças ao cacau, à castanha-do-pará, ao pirarucu. ${ }^{47} \mathrm{Na}$ área destas duas cidadezinhas, onde vivem não mais do que trinta mil pessoas, Ronca vê pessoalmente quase uma centena de italianos, quase todos provenientes de San Costantino di Rivello, minúsculo paese da Basilicata, a poucos quilômetros tanto da Calábria como da Campânia. Um dos pioneiros desta corrente migratória teria sido um tal Mileo, caldeireiro que se fixou no comércio em Óbidos, abrindo caminho a todos os outros.

Nas duas cidadezinhas, cerca de vinte casas comerciais administradas por italianos faziam então ótimos negócios, vendendo de tudo um pouco. Há alguns operários que encontram logo trabalho em ambiente que se encontra em contínuo desenvolvimento. Ninguém é agricultor; nenhum italiano parece ter sido atraído diretamente à arriscada aventura da coleta da borracha na floresta, como aconteceu com os nordestinos. Em quarenta anos, cerca de 300.000 nordestinos, impelidos pela seca, migraram do sertão para a Amazônia.

Os imigrantes italianos, com freqüência, aproveitavam o desenvolvimento do comércio da borracha, sem praticar o comércio ambulante como "regatões", a exemplo dos sírio-libaneses, ${ }^{48}$ mas radicando-se no minúsculo ambiente urbano de Óbidos e Santarém, onde também chegaram diversos franceses e alemães. ${ }^{49}$

46

47 As castancis "nozes brasileiras"; o "pirarucu", um dos maiores peixes de água doce do mundo, é também conhecido como o "bacalhau da Amazônia".

48 Cf. Truzzi, Libanais et Syriens au Brésil (1880-1950), cit.

49 São dados resultantes do registro de visitas a bordo do "Dogali", navio do capitão Ronca. Cf. Ronca, Dalle Antille alle Guyane e all 'Amazzonia, cit. 
Em Santarém criam-se alguns pequenos espaços culturais. Uma família italiana vende chapéus de Florença e corais napolitanos; a senhora Marietta Peluso funda uma pequena escola de música, na qual estudam duas de suas filhas que, emblematicamente, depois das primeiras experiências musicais na Amazônia e terminado o ciclo da borracha, transferem-se para o sul, em 1923, com toda a família. Em São Paulo encontrarão o sucesso: Rachel, como compositora e pianista, Gioconda, como soprano lírico. Em 1945 fundam juntas o "Instituto Musical Padre José Maurício", que dirigem por trinta anos. ${ }^{50}$

Enfim, inevitável destino de italianos na Amazônia é Manaus. Segundo o capitão Ronca, em 1905 há cerca de 2.000 conterrâneos na capital. Na verdade, uma quantia considerável, visto que a cidade então contava com menos de 45.000 habitantes. É provável que tenham chegado no final do século XIX, aproveitando também a linha de navegação Gênova-Manaus, que não terá longa vida, pois começa a funcionar em 1897 e termina em 1904. Logo, dos navios da Compagnia di Navigazione Ligure-Brasiliana desembarcaram também imigrantes, além de artistas de companhias líricas italianas, contratados para apresentar-se no luxuoso Teatro Amazonas, construído em 1896.

O projeto deste grande teatro, como se sabe, possuía seu impróprio modelo na Opera de Paris. Para a sua realização, foram utilizados mármores nas escadas, pórticos, estátuas e colunas; lustres de cristal, espelhos, vasos de porcelana e candelabros provenientes da Itália. Também a pintura do teatro é obra de um grupo de artistas italianos, chefiados pelo mesmo Domenico De Angelis que decorou o Teatro da Paz em Belém e que, em Manaus, durante 1888, já havia pintado a igreja de São Sebastião, projetada em 1870 pelo frade franciscano Gesualdo Marchetti. ${ }^{51}$ Sabe-se enfim que o Teatro Amazonas foi inaugurado em 1897, com a ópera La Gioconda, composta em 1876 por Amilcare Ponchielli, apresentada por uma companhia lírica italiana.

Portanto e ao menos em parte, competia aos artistas italianos proporcionar uma satisfação ao delirante "francesismo" da moder-

50 Ibidem; Carneiro, J. Pianista santarena morre em São Paulo, 4 abril de 2005 (http://jesocarneiro.blogspot.com/2005_04_01_jesocarneiro_archive.html); A ópera amazônica de Wilson Fonseca (entrevista), Fundação Carlos Gomes

(www.fcg.pa.gov.br/wf/entrevis.htm).

51 Cf. Monteiro. M. Ypiranga. Teatro Amazonas, I-III, Biblioteca Virtual do Amazonas (www.bv.am.gov.br/portal/conteudo/serie_memoria/36_teatro.php); Páscoa, M. Domenico De Angelis. Biblioteca Virtual do Amazonas

(www.bv.am.gov.br/portal/conteudo/serie_memoria/16_domenico.php). 
na elite da borracha. ${ }^{52}$ Tratou-se de uma presunção cultural que definitivamente, em Manaus, envolveu ainda o fenômeno da prostituição. Isto se for verdade que as prostitutas judias, provenientes da Europa centro-oriental, conhecidas em São Paulo e no Rio com o apelido depreciativo de "polacas", uma vez chegadas à Amazônia, em decorrência das restrições adotadas no final do século no sul do Brasil, transformaram-se em apreciadas e refinadas "francesas", quem sabe pelo porte ou por alguma frase aprendida em Paris. 53

É neste contexto que se insere o grande explorador-etnógrafo italiano Ermanno Stradelli (1852-1926) que, chegando à Amazônia em 1879, lá viverá por mais de quarenta anos, até morrer. Em outras palavras, vivenciou todo o ciclo da borracha, estudando as tradições indígenas, principalmente na região de Vaupés, em território colombiano, e exercitando a advocacia em Manaus. Partindo sempre de uma respeitosa e profunda compreensão às culturas indígenas, Stradelli tenta ainda ser um mediador entra a nova elite amazônica e a Itália. ${ }^{54} \mathrm{Em}$ 1897, quando começa a funcionar a linha de navegação Gênova-Manaus, subsidiada pelo governo amazônico para favorecer a vinda de artistas e de imigrantes italianos, Stradelli realiza uma viagem à Itália com o propósito de fundar uma companhia ítalo-brasileira no ramo da borracha. Mas a tentativa faliu e o etnógrafo italiano retorna definitivamente à Amazônia, transformada em sua pátria de adoção. ${ }^{55}$

Os italianos de Manaus, todavia, não são somente intelectuais, artistas, profissionais liberais ou comerciantes que contribuíam com a formação de uma nova e moderna identidade citadina, juntamente com portugueses, espanhóis, franceses e alemães, além de

\section{XX: desafio à construção de uma identidade étnica positiva no Brasil. Campos, 7 (1),}

Sobre este assunto veja-se: Gruman, M. A Prostitução Judaica no Início do Século 2006

(http://calvados.c3sl.ufpr.br/ojs2/index.php/campos/article/viewPDFInterstitial/ $5446 / 4001$

54 Cf. Daou, A. M. Instrumentos e sinais da civilização: origem, formação e consagração da elite amazonense. História, Ciência, Saúde-Manguinhos, vol. VI (suplemento), setembro de 2000 (www.scielo.br/scielo.php?pid=S010459702000000500006\&script=sci_arttext\&tlng=en).

55 Sobre Stradelli, lembra-se que sua contribuição antropológica é muito conhecida e apreciada na Colômbia, Venezuela e no Brasil, o que não acontece na Itália, cf. Stradelli, E. La Leggenda del Jurupary e outras lendas amazônicas. São Paulo: Istituto Cultural Italo-Brasileiro, 1964; Isenburg, T. Viaggiatori naturalisti italiani in Brasile nell'Ottocento. Mailano: Franco Angeli, 1989; Manera, D. Yurupari: i flauti dell'anaconda celeste. Milano: Feltrinelli, 1999. Para uma biografia de Stradelli, leia-se também: www.iclab.it/html/manera/stradelli.html. 
judeus e sírio-libaneses. Pois o capitão Ronca afirma que, em 1905, além de uma minoria constituída por comerciantes, empregados e operários em boas condições de vida, a comunidade italiana "conta pouco ou nada, porque é composta da gente pobre, sem ligação ou união entre si". Muitos desses pobres imigrantes - continua o oficial - já esqueceram a sua língua; quanto aos italianos abastados, precisariam falar português para serem entendidos. Escassa era a consideração de que os italianos desfrutavam na cidade, tanto que todos eram chamados de "carregadores" pela gente de Manaus.

Mas ainda há mais: Ronca suspeita que não eram poucos os italianos, desembarcados nos anos anteriores com os navios da Ligure-Brasiliana, que estariam dispersos nos seringais; adverte que o risco dos imigrantes na Amazônia é aquele de "transformar-se em escravo junto aos índios na floresta ou, na melhor das hipóteses, trabalhar junto aos negros como carregador".

O cenário é, portanto, mais complexo do que aquele observado nos outros estados e nas outras cidades. A Amazônia mostra o lado doloroso da migração italiana, comum também ao que aconteceu a milhares de nordestinos. Mas o complicado caso de Manaus, que não pode ser considerado como exemplo pelo seu caráter extremo e por vezes paradoxal, por si não transforma o resumido quadro da imigração italiana nas pequenas e médias cidades do nordeste e do norte do Brasil. $\mathrm{O}$ aspecto absolutamente predominante permanece aquele da ativa participação dos imigrantes nos processos de urbanização desenvolvidos na virada para o século XX, ainda que os italianos não alcançassem posições hegemônicas, não estivessem no vértice da hierarquia social, na grande maioria das vezes concentrando-se nas faixas sociais intermediárias. Por isso mesmo, contribuem em larga medida para desestruturar a polarização econômica e social típica de uma sociedade agrária em declínio.

\section{Na Colômbia}

Dirigimo-nos agora para outras latitudes, à procura de outras informações sobre um assunto apenas enunciado. Observamos o Caribe colombiano na virada para o século XX e o surgimento de 
Barranquilla como principal porto da Colômbia, na foz do Rio Magdalena. ${ }^{56}$

Barranquilla, que nos primeiros anos do século XIX era uma aldeia insignificante, no final do mesmo século tornou-se um centro agitado, habitado por 40.000 pessoas, entre as quais transitaram centenas de estrangeiros, sobretudo europeus, atraídos pelo comércio internacional, depois da abertura do Puerto Colombia, o principal porto para as importações e exportações colombianas, nas proximidades da cidade, que chegou à condição de principal porto do país. No censo de 1928, Barranquilla teve 140.000 habitantes, muito dos quais migrantes de regiões do interior, transformando-se na segunda cidade do país. Neste agitado ambiente comercial, naquelas alturas também industrial, são cerca de 4.400 os estrangeiros recenseados, sendo mais numerosos os espanhóis e os italianos, seguidos pelo sírio-libaneses. ${ }^{57}$

É necessário lembrar que os italianos, com exceção de alguns pioneiros lígures e de um pequeno grupo de origem toscana, chegam quase todos daquela parte do Apenino meridional da qual falamos desde o início e, principalmente, de Morano Calabro, Scalea, Padula e Castelnuovo di Conza. Trata-se quase sempre de artesãos e de agricultores pequenos proprietários, que se encontraram bem no pequeno comércio e no artesanato, conseguindo freqüentemente ampliar a atividade para o comércio atacadista, importação e exportação, à indústria, à navegação fluvial. Numerosos são os sapateiros, alfaiates, proprietários de armazéns, hotéis, restaurantes, os comerciantes de chapéus, vendedores de jóias e relógios, inclusive ambulantes. São italianos os pioneiros da indústria de calçados e, não raro, encontram-se italianos na indústria alimentícia e na construção civil. A agricultura e a criação de gado, ao invés, normalmente estão distantes dos seus interesses; alguma rara exceção tem, na realidade, o objetivo de aplicar maiores investimentos, sendo que é cada vez mais forte o estabelecimento no meio urbano.

No início do século XX, de Barranquilla derramam-se centenas de imigrantes ao longo do Rio Magdalena, parando nas encru-

56 Sobre o extraordinário desenvolvimento de Barranquilla e do Caribe colombiano na virada para o século XX, leia-se: Lemus, G. Bell (org.). El Caribe colombiano. Selección de textos históricos. Barranquilla: Ediciones Uninorte, 1988; Carbó, E. Posada. El Caribe colombiano. Una historia regional (1870-1950). Bogotá: El Áncora Editores, 1998; Donoso, J. Villalón (org.). Historia de Barranquilla, Barranquilla: Ediciones Uninorte, 2000. Cf., do último, as atas do "XIII Congreso de Colombianistas": AA.VV., Colombia y el Caribe. Barranquilla: Ediciones Uninorte, 2005.

57 Cf. Cappelli, Tra "Macondo" e Barranquilla, cit. 
zilhadas comerciais, de Calamar partindo a Magangué, Plato, Zambrano, El Banco, etc. Mas dirigem-se, sobretudo e oportunamente, na direção do enclave bananeiro criado pela empresa norteamericana United Fruit Company, entre Santa Marta e Fundación. Movimentam o comércio, moram nas povoações, vizinhos dos sírio-libaneses. Vão de Aracataca, onde nasceu Gabriel García Márquez, a Ciénaga, a pequena capital do enclave, onde acontecerá o "massacre das bananeiras", em 1928, tornado célebre na obra do prêmio Nobel colombiano, Cem anos de solidão. ${ }^{58}$ Deste território, no segundo pós-guerra, depois do fechamento da United Fruit, ao término do período de prosperidade bananeira, os italianos em grande número retornam às cidades portuárias, como Santa Marta e sobretudo Barranquilla.

É interessante e peculiar, no interior desta experiência imigratória no Caribe colombiano, a politização dos imigrantes provenientes de Morano Calabro, muitos dos quais jovens socialistas, preparados politicamente no paese de origem. Este componente político, que sustentou também culturalmente a formulação de uma escolha migratória, persiste de modo bastante ativo e evidente durante a década de 1920, apesar da ascensão do fascismo italiano ao poder. Depois, com o processo da integração e com a ascensão social de muitos, a inspiração socialista desaparece na adesão à maçonaria, cujo laicismo liberal, por outro lado, desenvolve um papel importante na virada para o século XX, naquela região colombiana de Cartagena a Santa Marta. Em Barranquilla, efetivamente, foram os maçons e os judeus a construírem e administrarem o novo cemitério citadino, inaugurado em 1870, despertando escândalo na oligarquia conservadora e na Igreja Católica local. De resto, maçons tinham sido os raros pioneiros da imigração italiana em meados do século XIX e, principalmente, em maçons transformaram-se mais tarde muitos comerciantes, pequenos empreendedores e artesãos, que fizeram da maçonaria um veículo para a mais rápida ascensão na sociedade local, posicionando-se nas camadas médio-altas, ${ }^{59}$ como também foi visto no caso brasileiro de Aracaju.

Tudo isto acontece com particular evidência na época do presidente Lopez Pumarejo, no próspero período de quinze anos da

58 Trata-se dos lugares onde o escritor viveu sua infância com os avós, relembrada como momento fundamental de sua formação, na recente autobiografia, onde não descuida de mencionar a presença de italianos naquele território: Márquez, G. García. Vivir para contarla. Barcelona: Mondadori, 2002, p. 26, 56, 183 [no Brasil: Viver para Contar. São Paulo: Record, 2003 - N. T.].

59 Cf. Cappelli, Entre inmigrantes, socialistas y masones, cit. 
história colombiana (1930-46), único liderado pelos liberaisradicais. ${ }^{60}$ Foi quando o acelerado desenvolvimento econômico de Barranquilla esteve acompanhado pelos mais efetivos processos de modernização, também sustentados pelo laicismo maçônico e amplamente facilitados no ambiente mercantil da cidade. Neste contexto, torna-se perfeitamente visível a contribuição italiana no processo de urbanização do Caribe colombiano que, em Barranquilla, se traduz também em investimentos imobiliários, com a construção por italianos de uma série de edifícios no centro histórico citadino.

Depois, ao eclodir a Segunda Guerra Mundial, o sucessivo alinhamento colombiano aos Estados Unidos e o correspondente congelamento dos bens dos italianos muito comprometeram uma posterior ascensão econômica e social da comunidade italiana, com vantagem para a ativa colônia sírio-libanesa, que continuava a crescer sem ser perturbada, apesar dos preconceitos relacionados aos árabes na sociedade local. Mais tarde, ao desencadear-se a violência do chamado "bogotazo", em 1948, em decorrência do assassinato do líder populista Eliécer Gaitán, ${ }^{61}$ a situação torna-se mais difícil e impede uma retomada da imigração, a qual, por outro lado, mesmo nas suas modestas dimensões, deixa de lado a costa do Caribe para ser atraída pelas cidades emergentes do interior e pela capital, onde se concentrará o desenvolvimento econômico industrial nas décadas sucessivas.

Nesses novos espaços, registrar-se-á uma presença italiana significativa no âmbito da urbanização. É bem verdade que, já no final do século XIX, a identidade urbana de Bogotà devia muito ao arquiteto florentino Pietro Cantini, projetista do Capitólio Nacional (1881) e do Teatro Colón (1885-95), e que, mais tarde, os Salesianos também estiveram muito presentes na arquitetura religiosa. Mas a

60 Alfonso López Pumarejo (Honda, 1886-Londres, 1959), duas vezes presidente da Colômbia, de 1934 a 1938 e de 1942 a 1945, é a figura central de um período único na história colombiana, recordado como a "república liberal". Naqueles anos, em enxurrada de decisões, entre muitos outros acordos, foi efetivado o acordo com as forças de esquerda, com uma legislação social que parecia uma provocação para as elites conservadoras locais. Também na área educacional, a inspiração laica e igualitária de López inquietava a oligarquia e o clero. Cf. Palacios, M.; Safford, F. Colombia. País fragmentado, sociedad dividida. Su historia. Bogotá: Editorial Norma, 2002, p. 536547; Stoller, R. Alfonso Lopez Pumarejo and Liberal Radicalism in 1930s Colombia. Journal of Latin American Studies, vol. 27, n. 2, 1995, p. 367-397.

61 Existe farta literatura sobre este evento traumático da história colombiana, mas leiase ao menos: Braun, H. Mataron a Gaitán: Vida pública y violencia urbana en Colombia. Bogotá: Universidad Nacional de Colombia, 1987 (nova edição: Bogotá: Editorial Norma, 1998). 
tumultuada urbanização no segundo pós-guerra impõe-se e aumenta a contribuição italiana no desenvolvimento urbano. Basta aqui lembrar as numerosas obras arquitetônicas de Bruno Violi (a começar pelo prédio da Faculdade de Engenharia, da cidade Universitária, em 1940) e a laboriosa empresa de construção "Ferroconcreto", de Luigi Concistrè, em Bogotá, a arquitetura de Renato Giovanelli, em Cali, e o trabalho de Luis De Marco, em Barranquilla. ${ }^{62}$

\section{Na América Central e Caribe}

Voltemos agora nossa atenção para o istmo centro-americano, iniciando pelo Panamá. Para que esta resenha não se torne muito pesada, apenas mencionamos a imigração italiana nesta região, onde tudo decorre em torno do projeto e da construção do Canal inter-oceânico, como se pode facilmente imaginar, compondo uma realidade excepcional, difícil de ser comparada à qualquer outra. Ali os italianos chegam preferencialmente de Castrovillari, na Calábria, e de Moliterno, na Basilicata -, uma primeira vez nos anos 80 do século XIX, ao tempo da falida tentativa de construção do Canal pelos franceses, quando o Panamá era ainda parte da Colômbia. E uma segunda vez, entre 1904 e 1914, durante a definitiva construção do Canal, por iniciativa do governo norte-americano que, no meio tempo, provocara a secessão de ampla área do estado colombiano. ${ }^{63}$ Nesse período, cerca de dois mil imigrantes eram aguadeiros, pedreiros ou operários, trabalhando junto aos negros "cavadores" antilhanos. A sua condição talvez possa ser semelhante àquela dos italianos de Manaus, descrita pelo Capitão Ronca,

62 Para uma documentação sobre o assunto é fundamental a revista Proa, publicada em Bogotá, pela "Sociedad Colombiana de Arquitectos", em 1946. Mas leia-se especialmente: Obra arquitectónica de Bruno Violi. Proa, n. 23, 1949; Colegio Italiano Galileo Galilei, Barranquilla. Proa, n. 435, 1997. Cf. Além disso: Ardila, J. Ernesto Cantini. Pietro Cantini. Semblanza de un arquitecto. Bogotá: Corporación de La Candelaria, 1990; Tascón, R. La arquitectura moderna en Cali. La obra de Borrero, Zamorano y Giovanelli. Cali: Fundación Civilis, 1995; Varini, C. Bruno Violi. Arquitecturas y Lirismo Matérico. Bogotá: Impreandes, 1998; Asociación pro Rescate de Archivos de Arquitectura. Los archivos colombianos de arquitectura del siglo XX, El Fondo Buscaglione. Boletín Cultural y Bibliográfico, n. 66, 2004. Leia-se, enfim, a entrevista com Luigi Concistrè: La Arquitectura Colombiana, una de las Mejores del Continente. El Bolivariano, 27 abril de 1957.

63 Cf. Cuestas, C. Presencia y contribuciones de los Italianos en el Istmo de Panamá. In: Gólcher, Ileana (org.). Este País, un Canal: Encuentro de Culturas. Panamá: Editora Sibauste, 1999; Boni, D. Dal. Panamá, Italia y los italianos en la época de la construcción del Canal (1880-1915). Panamá: Crucero de Oro, 2000; Cappelli, Verso le Americhe, cit. 
que antes recordamos. Em pouco tempo, entretanto, também no Panamá emerge a verdadeira vocação destes imigrantes: aqueles que não retornam à pátria se afastam da zona do Canal e preferem a vida urbana da pequena capital, onde se dedicam ao comércio e aos ofícios artesanais, integrando-se plenamente na sociedade local e transformando-se, enfim, em componente significativo das categorias profissionais e das atividades comerciais da cidade, apesar da sua modesta consistência numérica. ${ }^{64}$ Também neste caso, não falta a reconhecida contribuição intelectual e artística: é um arquiteto italiano, Gennaro Ruggieri, o projetista do Teatro Nacional e do Palácio do Governo. E por fim, no vértice da política teremos em tempos sucessivos personagens importantes de origem italiana, como três presidentes da república: Rodolfo Chiari, 1924-28; Roberto Chiari, 1960-64; Nicolas Ardito Barletta, 1984-85.

Deslocamo-nos agora para um país limítrofe, Costa Rica. Ali, depois de uma primeira imigração organizada e constituída por cerca de 1.500 operários, contratados em território mantovano para trabalhar na construção da ferrovia Puerto Limón-San José, a presença italiana é quase exclusivamente resultante de um fluxo imigratório espontâneo, proveniente de Morano Calabro. Trata-se de centenas de grupos familiares que se inserem em San José e no Valle Central, o coração urbano e econômico da pequena Costa Rica, onde em fins da década de 1920, os estrangeiros são 10\% da população, com os italianos em segundo lugar, logo após os espanhóis. ${ }^{65}$

Este singular país centro-americano vive, no início do século XX, um agitado período de modernização, baseado na exportação de café e de banana, insolitamente sustentado por uma robusta categoria social composta por pequenos e médios proprietários de terra, de tecido social equilibrado, na maior parte das vezes, e com regras democráticas bastante precisas, que fazem da Costa Rica uma feliz exceção, no contexto do caribenho e centro-americano, idealizada na imagem estereotipada de uma Suiça dos Trópicos. ${ }^{66}$ Neste quadro, a imigração moranesa dirige-se em grande parte para a pequena capital, San José, estabelecendo-se com pensões,

64 Cappelli, Nelle altre Americhe, cit.; Cappelli, Entre inmigrantes, socialistas y masones, cit.

65 Cf. Bariatti, R. Italianos en Costa Rica (1502-1952). De Cristóbal Colón a San Vito de Java. San José: Universidad Autónoma de Centroamérica/Costa Rica, 2001; Cappelli, Nelle altre Americhe, cit., p. 63-68.

66 Sobre este assunto, leia-se a aguda intervenção de V. H. Acuña Ortega. La invención de la diferencia costarricense. Revista de Historia, n. 45, 2002, p. 191-228. Para uma análise de longo período, cf. Ortega, V. H. Acuña; Molina, I. Historia económica y social de Costa Rica (1750-1950). San José: Editorial Porvenir, 1991. 
armazéns, sapatarias, alfaiatarias; também não são raros aqueles que se dedicam à indústria alimentar e ao comércio internacional. O recenseamento de 1927 já mostra claramente a integração desta imigração e o sucesso de muitos: a comunidade italiana de San José conta oficialmente com 427 indivíduos, que são prevalentemente comerciantes e artesãos (40\%), afirmando assim a sua vocação para o trabalho independente e para a inserção urbana; não poucos são profissionais liberais e industriais (6\%); o analfabetismo é quase inexistente e as mulheres alcançam $46 \%$ da colônia, consagrando assim o caráter permanente da imigração e, por outro lado, confirmando o fato de que mais da metade desta colônia já é de segunda geração, sendo nascidos na Costa Rica 238 sobre 427 indivíduos. ${ }^{67}$

Entre os aspectos peculiares desta experiência imigratória, é preciso registrar também uma destacada conotação política. Se aos operários mantovanos é atribuída a primeira greve da história do país, organizada durante a construção da ferrovia (1888), no início do novo século percebe-se a emergência da inspiração socialista entre muitos moraneses. A sua fé política, adquirida junto a um círculo socialista ativo em Morano desde a década de 1890, encontraria modo de manifestar-se também na imigração, muito mais do que no Caribe colombiano, graças à moderna dialética democrática da Costa Rica. Tanto é que, nas décadas de 1910, 20 e 30, diversos imigrantes provenientes de Morano participaram ativamente do surgimento do movimento socialista e, depois, do partido comunista costa-riquense. Sucessivamente, ali como em outras partes, o processo de integração social e o sucesso econômico de muitos conduzem ao gradual abandono da militância socialista, mas não ao conformismo, nem à adesão generalizada e passiva ao fascismo italiano. Ao contrário, uma parte consistente da colônia permanecerá antifascista até o início da Segunda Guerra Mundial, guiada pelo romano Adriano Arié, líder muito ativo, anárquico na juventude que, até os anos 1930, mantém viva na comunidade italiana a tradicional festa laica e maçônica de 20 de Setembro, aniversário da conquista de Roma pelo exército italiano e, conseqüentemente, comemoração do fim do Estado Pontifício (1870), evento também celebrado durante muito tempo, diga-se de passagem, entre os italianos da Colômbia. ${ }^{68}$

Superada a crise dos anos de guerra, quando foram congelados os bens dos italianos e encerrada a breve guerra civil de 1948,

67 Bariatti, Italianos en Costa Rica, cit., p. 232.

68 Cf. Cappelli, Entre inmigrantes, socialistas y masones, cit. 
a Costa Rica retoma a sua equilibrada via de desenvolvimento, que permitirá a inserção de novos imigrantes na década de 1950 . O êxito visível desta experiência imigratória aponta para cerca de três mil pessoas inscritas nos registros consulares, grupo acrescido de aproximadamente dez mil costa-riquenses de origem italiana, que pertencem em geral à classe média-alta e que ocupam, muitas vezes, postos de relevo no meio acadêmico, cultural e artístico. Quanto ao desenvolvimento urbano, é útil lembrar que um dos lugares mais significativos e emblemáticos da cultura e da identidade costa-riquense, o Teatro Nacional de San José (1897), é reconhecido como obra de projetistas, artistas e mestres-de-obras italianos, e que, na construção civil relacionada à fixação da comunidade italiana, encontram-se alguns aspectos arquitetônicos interessantes. 69

Observamos por fim o caso da Guatemala. Ali os imigrantes devem considerar a alteridade étnica e cultural de uma população inteiramente indígena e mestiça, com uma vida política dominada por restrita oligarquia, assim como por brutais ditaduras pessoais, com um único intervalo representado pela revolução democrática de Arévalo e Arbenz (1944-1954). ${ }^{70}$ Tais circunstâncias dão lugar a um ambiente por demais diferente com relação à Costa Rica; além de ter uma população branca, com exceção de Puerto Limón, o país é caracterizado por democracia e relativo equilíbrio social. Também na Guatemala, depois de uma primeira imigração agrícola proveniente do Trentino, na década de 1870, entre o final do século XIX e a década de 1920 ingressam no país cerca de mil pessoas ou um pouco mais, provenientes em grande parte de Morano Calabro, dirigindo-se aos ambientes urbanos, na capital e em Quetzaltenango. O filão imigratório mais interessante é aquele que escolhe como destino esta última cidade, situada a 2.300 metros de altitude, histórica capital de Los Altos, uma região interna e mon-

69 É o caso do modernismo da residência de Adriano Ariè (1910), pintor, decorador e projetista, além de líder da comunidade italiana, ou da inspiração racionalista da casa construída pelo comerciante Carmelo Ingianna em San José (1930ca). Cf. Avendaño, F. Quesada. El ambiente de la élite. Modernidad, segregación urbana y transformación arquitectonica: San José, Costa Rica, 1890-1935. Scripta Nova, vol. VII, n. 146 (027), agosto de 2003 (www.ub.es/geocrit/sn/sn-146(027).htm); Cappelli, Nelle altre Americhe, cit. Sobre o Teatro Nacional, cf. Bariatti, Italianos en Costa Rica, cit.

70 Para um enquadramento das experiências políticas da Guatemala no contexto centro-americano, cf. Pompejano, D. Storia e conflitti del Centroamerica. Gli stati d'allerta. Firenze: Giunti, 1991. Sobre o dramático final do decênio democrático de Arévalo e Arbenz, idealizado e organizado pela CIA e pelo Departamento de Estado NorteAmericano, leia-se Vattano, L. Il Guatemala del 1954: esordi della psywar. Passato e Presente, n. 63, settembre-dicembre 2004, p. 97-111. 
tanhosa, habitada quase que exclusivamente por índios de origem maia. ${ }^{71}$

Até o fim do século XIX, em Quetzaltenango desenvolve atividades um surpreendente núcleo de arquitetos, construtores e artistas italianos, sendo alguns membros ativos das lojas maçônicas. ${ }^{72}$ Portanto, a indústria da construção, mas também o comércio e as atividades artesanais, são espaços de imigrantes italianos. E, quando a cidade é atingida por um terremoto, em 1902, a sucessiva obra de reconstrução reforça ainda mais a sua ativa presença. Curtumes, fábricas de calçados, indústrias têxteis e alfaiatarias são fundadas por imigrantes provenientes quase sempre de Morano Calabro. De Castrovillari, a poucos quilômetros de Morano, chega um carpinteiro socialista, Carmine Rimola, cujo percurso biográfico é verdadeiramente emblemático da evolução da comunidade italiana: no espaço de poucos anos este carpinteiro "subversivo" torna-se "arquiteto" e constrói o edifício do "Banco de Occidente" (1902), em estilo neo-renascentista, o "Instituto Normal para Varones de Occidente" (1907-14), com a fachada em estilo coríntio, e o "Monumento al León" (1910), dedicado ao ditador guatemalteco Estrada Cabrera. Nos anos vinte, Rimola torna-se presidente da "Società Italiana di Beneficenza" e é membro de uma loja maçônica. ${ }^{73}$

Fica evidente que o socialismo juvenil, partilhado até os anos vinte com inúmeros outros imigrantes, quase sempre artesãos chegados de Morano, não só entra em conflito com as ambições econômicas e sociais cultivadas pelos imigrantes, mas logo resulta impraticável em função do contexto político, caracterizado por uma sucessão quase ininterrupta de ditaduras militares que, no curso do século XX, tornaram persistente o domínio brutal da oligarquia sobre a população indígena. ${ }^{74}$

Ao final do mesmo século, todavia, restam amplos traços da presença italiana como, por exemplo, marcas do estilo clássico nas construções, dotadas de ambições monumentais nos primeiros anos do século. Mas estes traços encontram-se também na ativida-

\footnotetext{
Cappelli, Nelle altre Americhe, cit., p. 68-73.

72 Cf. Arriola, A. Taracena. La arquitectura regional quetzalteca: una proposición de "unidad cultural". Centroamericana, n. 10, 2002.

73 Cappelli, Entre inmigrantes, socialistas y masones, cit., p. 350.

74 Uma atenta reconstrução da história contemporânea guatemalteca, escrita ao término de decênios de conflito armado, está no acurado relatório Guatemala: memoria del silencio (http://shr.aaas.org/guatemala/ceh/mds/spanish/cap1/cap1.html), produzido por uma "Comisión para el Esclarecimiento Histórico" (CEH), propositalmente constituída.
} 
de comercial, na pequena indústria e nas profissões liberais. Por fim, no campo literário, a imigração italiana deixou alguns suas marcas: Mario Monteforte (1911-2003) tem um sobrenome napolitano, e é talvez o mais importante escritor guatemalteco depois do Prêmio Nobel, Miguel Angel Asturias; o escritor Dante Liano (1948) é de origem calabresa, precisamente de Guardia Piemontesa; Isabel Garma é o pseudônimo de Norma García Mainieri (19401998), descendente pelo lado materno de imigrantes moraneses, poetisa feminista e escritora fortemente empenhada na comunidade.

Esta resenha poderia continuar com o exame da presença italiana em Cuba, contando sobre os 300 ou 400 ex-camponeses que passaram sapateiros a fabricar chinelos em Habana, nos anos 1929, e sobre os vendedores ambulantes de jóias chegados de Padula;75 poder-se-ia ainda avançar com a lembrança dos italianos em Santo Domingo, provenientes quase todos de Santa Domenica Talão, ${ }^{76}$ um outro pequeno paese calabrês que parece haver seguido um desígnio das estrelas que teriam desejado promover um encontro, em alguma ilha do Caribe, de dois santos homônimos: a calabresa Santa Domenica di Tropea e o bem mais célebre Santo Domingo de Guzmán. A esta altura, é o caso de passar a algumas observações conclusivas.

\section{Conclusões}

Das histórias que contamos emerge - espera-se - que, de territórios rurais e montanhosos da Itália meridional, partem espontaneamente fluxos migratórios, fortemente motivados, que oferecem uma importante contribuição para a construção de uma moderna rede urbana, em vários países e regiões da América Latina, que foram apenas tocados pela grande migração de massa. Isto acontece através do desenvolvimento de múltiplas correntes e redes imigratórias, movimentadas por artesãos e camponeses, mas também por comerciantes, construtores e artistas, que deixam a Itália não para serem agricultores em campos desconhecidos por colonizar, mas para ajustar-se com a construção da modernidade de portos e cidades em ascensão, na virada para o século XX. Co-

75 Cf. Appelius, M. Le isole del raggio verde (Cuba, Giamaica, Haiti, Portorico e Piccole Antille). Milano: Edizioni Alpes, 1929, p. 93-103. Sobre a presença italiana em Cuba é imprescindível o trabalho de Domenico Capolongo. Cf. Capolongo, D. Emigrazione e presenza italiana in Cuba, voll. I-IV. Roccarainola: Circolo Culturale Duns Scoto, 20022005.

76 Cf. Azcárate, Los italianos en America, cit. 
mo vimos, esses imigrantes, por vezes, não são privados de consciência política, mais precisamente, alimentam convicções socialistas e, com muita freqüência, o seu direcionamento ao moderno e urbano no novo mundo passa através da participação ativa na maçonaria, algumas vezes já conhecida na pátria.

Há um repertório de histórias esquecidas ou desconhecidas que muitas vezes resultam surpreendentes. A surpresa deriva não só do fato de que a historiografia até hoje não se ocupou adequadamente do assunto, mas também da contradição clamorosa que reduz essa experiência imigratória a estereótipos consolidados, que dizem respeito ao presumido "atraso" pré-moderno na migração dos italianos do sul em relação aqueles do norte, assim como na "marginalidade" das regiões e dos países latino-americanos, considerados irremediavelmente periféricos com respeito ao coração metropolitano e industrial da Argentina e do Brasil. Não será inútil recordar, a propósito de estereótipos deste tipo desmentidos pela realidade e, apesar disso, persistentes que, de uma investigação solicitada por Zanardelli, chefe do governo italiano, já em 1902 na Basilicata - são palavras textuais - notava-se "uma emigração especialíssima", movimentada, sobretudo, por artesãos, dirigida a lugares insólitos da América Latina, que produzira extraordinário "e prático conhecimento das condições materiais e políticas dos países sul-americanos", que não se encontrava nem mesmo em Gênova e na Liguria, "onde multiplica-se o elemento marinheiro".77

Por fim, o cenário desta surpresa que procuramos descrever talvez também precise registrar que as pequenas comunidades italianas que individualizamos foram protagonistas de um veloz processo de integração nas realidades que acolheram, a ponto de desatarem totalmente os laços com a pátria italiana ou com a pequena pátria representada pelo paese de origem. De fato, raramente permaneceram fortes ligações identitárias com as origens, como aconteceu em Porto Alegre, com os calabreses de Morano, ou nas colônias do interior do Rio Grande do Sul, com os vênetos. Ao contrário, se observa uma rápida assimilação ao novo mundo e, como exemplo, cita-se dois casos: o filho de um calabrês de San Nicola Arcella publica na Colômbia um Lexicón de colombianismos e, na Costa Rica, o filho sociólogo de um imigrante de Castrovillari

77 Assim se exprime o relator da pesquisa, Ausonio Franzoni. Cf. Franzoni, A. L'emigrazione in Basilicata. Tipografia Nazionale Bertero, 1904. 
publica um estudo sobre Los estereotipos del costaricense. ${ }^{78}$ Pretendese dizer que, em qualquer caso, a segunda geração encontra-se em condição de ler cientificamente e de dominar criticamente a identidade adquirida, talvez pouco sabendo sobre aquela dos pais e, logo, tanto menos conservá-la.

Talvez só com as últimas gerações tenha emergido a exigência de descobrir as distantes origens familiares, mas isto provavelmente tem a ver, sob meu ponto de vista, com as perdas produzidas pela marmelada social pós-moderna, que impõe a procura de um porto firme. Assim que, de uma América Latina agora patologicamente hiper-urbanizada, as últimas gerações de ítaloamericanos - que descendem daqueles imigrantes que contribuíram para fundar a modernidade urbana latino-americana entre os séculos XIX e XX -, têm vontade, com freqüência, de descobrir desbotadas raízes familiares, refazendo às avessas o percurso dos avós para, quem sabe, reencontrar nos pequenos paesi campânios, lucanos ou calabreses, a sugestão e o enriquecimento de sentido para a vida presente, ou talvez somente um passaporte, útil para fazer a vida mais fácil ou para encontrar a fortuna mais adiante...

78 Trata-se de Mario Alario Di Filippo (Lexicón de colombianismos. Cartagena de Índias: Editora Bolívar, 1964) e Gaetano Cersosimo (Los estereotipos del costaricense. Heredia: Biblioteca Universidad Nacional, 1985), filhos respectivamente de Vladimiro Alario (San Nicola Arcella, 1885), emigrado para a Colômbia em 1913, e de Giovanni Cersosimo (Castrovillari, 1903), imigrado na Costa Rica nos anos imediatamente sucessivos à Primeira Guerra Mundial (Cf. Cappelli, Nelle altre Americhe, cit., p. 114 e 199). 